\title{
Pengaruh Book Tax Differences dan Struktur Kepemilikan Saham terhadap Persistensi Laba
}

\author{
Endah Lailatul Mu'arofah, Ihyaul Ulum, Gina Harventy \\ Fakultas Ekonomi dan Bisnis Universitas Muhammadiyah Malang \\ Jl. Raya Tlogomas No. 246, Malang \\ Email: eendah8@gmail.com
}

\begin{abstract}
The aim of this study is to get empirical evidence about the influence of book tax differences (BTD) and managerial ownership to earnings persistence. BTD is separated into normal BTD and abnormal BTD, and classified into positive BTD and negative BTD. There are four components that are tested in BTD, namely large positive abnormal BTD (LPABTD), large negative abnormal BTD (LNABTD), large positive normal BTD (LPNBTD), and large negative normal $B T D$ (LNNBTD). The ownership structure that tested is managerial ownership. This research uses multiple linear regression analysis with population of manufacturing companies in Indonesia Stock Exchange. The result shows that companies with LPABTD, LNABTD, and LPNBTD have higher earnings persistence than companies without the components. Conversely, companies with LNNBTD have lower earnings persistence than companies without the components. The structure of managerial stock ownership increases the earnings persistence unless the companies have large negative normal BTD.
\end{abstract}

Key words: book tax differences, earnings persistence, managerial ownership, tax planning.

\section{PENDAHULUAN}

Kualitas laba pada perusahaan-perusahaan di Indonesia masih rendah, berbeda dengan beberapa negara maju seperti Amerika Serikat dan Australia yang termasuk negara dengan kualitas laba perusahaan yang tinggi (Boulton et al., 2011). Hal ini menyebabkan turunnya kepercayaan investor terhadap kualitas laba perusahaan. Salah satu pengukuran kualitas laba yang berdampak pada peningkatan informasi laba sehingga menarik kepercayaan investor adalah persistensi laba (Tucker dan Zarowin, 2006).

Persistensi laba adalah revisi laba yang mencerminkan kualitas laba perusahaan dan menunjukkan bahwa perusahaan dapat mempertahankan laba dari waktu ke waktu (Harahap, 2011). Laba tersebut dinamakan laba akuntansi (laba komersial), laba ini akan dijadikan sebagai dasar dalam pengenaan pajak. Besarnya laba akuntansi (komersial) berbeda dengan laba fiskal akibat adanya perbedaan aturan akuntansi dalam Standar Akuntansi Keuangan dengan aturan perpajakan berdasarkan Undang-undang perpajakan. Selisih antara perhitungan laba akuntansi dan laba fiskal ini biasa disebut dengan book tax differences.

Book tax differences (BTD) dibagi menjadi dua sumber yaitu normal dan abnormal. Normal book tax differences (NBTD) adalah book tax differences yang bersumber dari perbedaan peraturan antara akuntansi dan pajak. Sedangkan abnormal book tax differences (ABTD) adalah book tax differences yang bersumber dari aktivitas oportunis perusahaan seperti manajemen pajak dan manajemen laba (Tang dan Firth, 2012).

Penelitian mengenai pengaruh book tax differences terhadap persistensi laba telah dibuktikan secara empiris oleh Tang dan Firth (2012) dengan setting negara Cina. Analisis regresi dilakukan untuk menguji persistensi laba, sebelumnya dila-

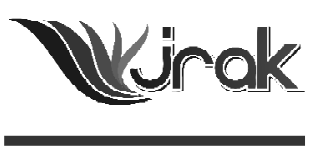

Jurnal Reviu Akuntansi dan Keuangan ISSN: 2088-0685 Vol.5 No. 1, April 2015 Pp 673-682 


\section{Pengaruh \\ Book Tax \\ Differences...}

674 kukan estimasi nilai NBTD dan ABTD terlebih dahulu dengan cara melakukan regresi BTD yang menghasilkan residual value (ABTD) sedangkan NBTD diukur dengan selisih antara ABTD dan BTD. Hasil penelitian membuktikan bahwa NBTD dan ABTD yang besar baik positif maupun negatif memiliki tingkat persistensi laba lebih rendah daripada perusahaan dengan nilai NBTD dan ABTD kecil baik positif maupun negatif. Namun, tingkat persistensi laba untuk perusahaan ABTD besar secara signifikan lebih rendah daripada bagi perusahaan NBTD besar.

Penelitian Sismi dan Martani (2014) menggunakan data panel untuk menguji pengaruh perbedaan laba akuntansi dengan laba pajak dan kepemilikan keluarga terhadap persistensi laba pada perusahaan yang terdaftar di Bursa Efek Indonesia. Hasil penelitian menunjukkan bahwa keseluruhan faktor pembentuk BTD memengaruhi BTD secara signifikan. Uji persistensi laba menunjukkan bahwa BTD dengan besar dan/atau sumber yang berbeda memberikan pengaruh berbeda pula terhadap persistensi laba. Penelitian ini dapat menunjukkan bahwa kepemilikan keluarga mengurangi persistensi laba kecuali saat perusahaan memiliki nilai BTD besar dan negatif karena aktivitas manajemen laba dan pajak.

Wardana dan Martani (2014) menggunakan 131 perusahaan yang terdaftar di BEI sebagai sampel penelitian. Penelitian ini menguji pengaruh book-tax differences dan struktur kepemilikan terhadap relevansi laba menggunakan analisis regresi selanjutnya dilakukan uji robustness dengan tujuan semakin menguatkan hasil regresi sebelu mnya. Hasil penelitian menunjukkan normal book tax differences berpengaruh negatif terhadap relevansi laba dan abnormal book tax differences berpengaruh positif terhadap relevansi laba sedangkan kepemilikan keluarga dan institusional tidak berpengaruh terhadap relevansi laba.

Selain periode penelitian yang berbeda dengan peneliti sebelumnya, penelitian ini juga menambahkan variabel struktur kepemilikan saham manajerial dalam menentukan tingkat persistensi laba perusahaan. Penelitian tentang persistensi laba menjadi penting dilakukan karena mengingat pentingnya peran laba bagi investor sebagai dasar pengambilan keputusan.

Selain itu, adanya perbedaan tarif dan peraturan perpajakan di berbagai negara membuat penelitian ini penting dilakukan untuk membuktikan apakah book tax differences berdasarkan peraturan perpajakan di Indonesia dapat memberikan informasi mengenai persistensi laba pada perusahaan-perusahaan di Indonesia.

Penelitian ini akan membuktikan secara empiris pengaruh komponen book tax differences terhadap persistensi laba. Selain itu juga membuktikan pengaruh struktur kepemilikan saham terhadap persistensi laba. Dalam hal ini, struktur kepemilikan saham yang digunakan adalah kepemilikan manajerial.

\section{TEORI DAN PENGEMBANGAN HIPOTESIS}

Selisih laba akuntansi dan laba pajak terjadi karena adanya perbedaan peraturan yang berbeda antara standar akuntansi dengan peraturan perpajakan. Hal tersebut mengakibatkan transaksi yang sama bisa dicatat dengan nilai yang berbeda akibat adanya perencanaan pajak. Adanya informasi manajemen laba dan perencanaan pajak yang terkandung dalam ABTD maka semakin melemahkan persistensi laba. Sesuai dengan agency theory, motivasi dalam melakukan aktivitas oportunis perusahaan melalui aggressive accounting akan mengarah pada overstate earnings. Laba yang mengarah pada overstate earnings mengakibatkan laba menjadi kabur (opaque) (Beaver, 2002).

Berdasarkan penelitian Tang dan Firth (2012) membuktikan bahwa perusahaan yang memiliki nilai NBTD dan ABTD yang besar baik positif maupun 
negatif memiliki tingkat persistensi laba lebih rendah daripada perusahaan dengan nilai NBTD dan ABTD kecil baik positif maupun negatif. Selain itu, penilaian ini juga menemukan bukti empiris bahwa perusahaan dengan nilai ABTD absolut yang besar memiliki tingkat persistensi laba lebih rendah daripada perusahaan dengan nilai NBTD absolut yang besar.

Berbeda dengan penelitian Sismi dan Martani (2014) pada komponen ABTD terbukti bahwa perusahaan yang melakukan aktivitas manajemen laba dan manajemen pajak memiliki persistensi laba lebih rendah. Perusahaan yang melakukan aktivitas manajemen laba dan manajemen pajak lebih tinggi baik positif maupun negatif memiliki persistensi laba lebih rendah daripada perusahaan yang melakukan aktivitas tersebut dengan intensitas kecil. Perusahaan dengan NBTD positif yang besar tidak terbukti memiliki persistensi laba yang lebih rendah, namun sebaliknya justru memiliki persistensi laba yang lebih tinggi. Hal tersebut dikarenakan NBTD terjadi karena perbedaan regulasi akuntansi dan pajak serta sesuai dengan karakteristik perusahaan. Perusahaan dengan NBTD negatif besar terbukti memiliki persistensi yang lebih rendah. Komponen ini juga terbukti memiliki persistensi laba lebih rendah daripada komponen NBTD bernilai kecil. Hal ini dikarenakan perusahaan dengan NBTD negatif mengindikasikan adanya pembayaran pajak yang lebih besar dimasa sekarang atau tax planning yang kurang efektif. Hal ini memengaruhi persistensi laba karena dimasa mendatang deffered tax asset belum pasti dapat direalisasikan. Dengan demikian hipotesis yang digunakan adalah:

$\mathrm{H}_{1}$ : Semakin perusahaan memiliki perbedaan laba akuntansi dan laba pajak dari sumber abnormal dengan nilai positif dan besar (LPABTD) maka persistensi laba semakin rendah daripada perusahaan lain tanpa komponen LPABTD.

$\mathrm{H}_{2}$ : Semakin perusahaan memiliki perbedaan laba akuntansi dan laba pajak dari sumber abnormal dengan nilai negatif dan besar (LNABTD) maka persistensi laba semakin rendah daripada perusahaan lain tanpa komponen LNABTD.

$\mathrm{H}_{3}$ : Semakin perusahaan memiliki perbedaan laba akuntansi dan laba pajak dari sumber normal dengan nilai yang positif dan besar (LPNBTD) maka persistensi laba semakin tinggi daripada perusahaan lain tanpa komponen LPNBTD.

$\mathrm{H}_{4}$ : Semakin perusahaan memiliki perbedaan laba akuntansi dan laba pajak dari sumber normal dengan nilai yang negatif dan besar (LNNBTD) maka persistensi laba semakin rendah daripada perusahaan lain tanpa komponen LNNBTD.

Kepemilikan manajerial adalah persentase jumlah kepemilikan saham oleh pihak manajemen dari seluruh modal saham perusahaan yang dikelola (Boediono, 2005). Menurut Siallagan dan Machfoedz (2006) semakin besar persentase kepemilikan manajemen dalam perusahaan maka semakin besar pula kecenderungan manajemen untuk meningkatkan kinerja mereka yang berpengaruh pada kehandalan pelaporan informasi keuangan perusahaan. Selain itu bukti empiris yang mendukung yaitu dari penelitian Khafid (2012) menyatakan kepemilikan saham oleh manajemen/kepemilikan manajerial berpengaruh positif terhadap persistensi laba. Perusahaan dengan kepemilikan manajerial yang semakin besar, semakin meningkat persistensi labanya, dan cenderung memiliki laba yang sustainable. Berdasarkan uraian tersebut maka hipotesis yang diajukan dalam penelitian ini adalah:

$\mathrm{H}_{5}$ : Semakin perusahaan memiliki struktur kepemilikan saham oleh manajerial maka persistensi laba semakin tinggi daripada perusahaan lain yang tidak memiliki struktur kepemilikan saham manajerial. 


\section{Pengaruh \\ Book Tax \\ Differences...}

676

Gambar 1

Kerangka Pemikiran

Penelitian

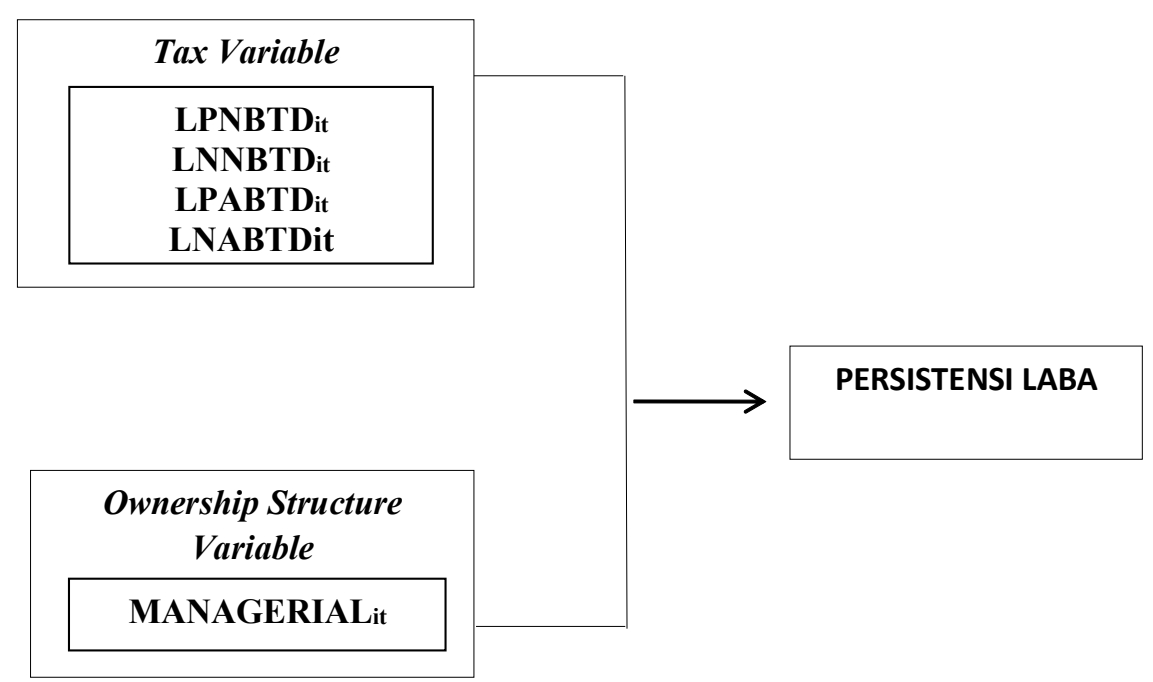

\section{METODE}

\section{Model Estimasi Komponen BTD}

Penelitian ini menggunakan adaptasi dari model penelitian Tang dan Firth (2012) dimana komponen BTD dibagi menjadi dua yaitu NBTD dan ABTD. Untuk mendapatkan komponen BTD tersebut harus dilakukan regresi terlebih dahulu. seluruh variabel pada persamaan regresi BTD di bawah ini akan diskalakan dengan nilai total aset rata-rata pada tahun $t$ untuk mengontrol pengaruh firm size. Setelah itu diurutkan berdasarkan kuartil dan dibedakan untuk BTD positif maupun negatif dari sumber normal dan abnormal untuk menentukan LPABTD, LNABTD, LPNBTD, dan LNNBTD. Persamaan regresi yang digunakan diadaptasi dari penelitian Tang dan Firth (2012).

$$
\text { BTDit }=\beta 0+\beta 1 \Delta \mathrm{INVit}+\beta 2 \Delta \mathrm{REVit}+\beta 3 \mathrm{BTDit} " 1+\varepsilon i t
$$

\begin{tabular}{cl}
\hline Variabel & \multicolumn{1}{c}{ Keterangan } \\
\hline $\mathrm{BTD}_{\text {it }}$ & $\begin{array}{l}\text { book-tax different perusahaan } i \text { pada tahun } \mathrm{t} \text {, selisih nilai laba } \\
\text { akuntansi dengan laba pajak }\end{array}$ \\
& $\begin{array}{l}\text { Perubahan investasi property, aset tetap, dan aset tak berwujud } \\
\text { perusahaan } i \text { dari tahun } \mathrm{t}-1 \text { ke tahun } \mathrm{t}\end{array}$ \\
$\Delta \mathrm{INV}_{\mathrm{it}}$ & $\begin{array}{l}\text { perubahan pendapatan perusahaan } i \text { dari tahun } \mathrm{t}-1 \text { ke tahun } \mathrm{t} \\
\text { nilai BTD pada tahun } \mathrm{t}-1, \text { untuk memperhitungkan pengaruh } \\
\text { perubahan standar akuntansi dan perpajakan dari tahun ke } \\
\text { tahun pada NBTD }\end{array}$ \\
\hline
\end{tabular}

\section{Model Persistensi Laba}

Pengujian hipotesis dalam penelitian ini menggunakan adaptasi model penelitian (Tang dan Firth, 2012).

Model pengujian hipotesis 1:

$\mathrm{E}_{\mathrm{t}+1}=\beta 0+\beta 1 \mathrm{E}_{\mathrm{t}}+\beta 2$ LPABTD $_{\mathrm{t}}+\beta 3\left(\mathrm{E}_{\mathrm{t}}\right.$ * LPABTD $\left._{\mathrm{t}}\right)+\beta 4$ MANAGERIAL $_{\mathrm{t}}+$ $\beta 5\left(\right.$ MANAGERIAL $\left._{\mathrm{t} *} \mathrm{E}_{\mathrm{t}}\right)+\varepsilon_{\mathrm{t}}$

Model pengujian hipotesis 2:

$\mathrm{E}_{\mathrm{t}+1}=\beta 0+\beta 1 \mathrm{E}_{\mathrm{t}}+\beta 2$ LNABTD $_{\mathrm{t}}+\beta 3\left(\mathrm{E}_{\mathrm{t}}\right.$ * LNABTD $\left._{\mathrm{t}}\right)+\beta 4$ MANAGERIAL $_{\mathrm{t}}+$ $\beta 5\left(\right.$ MANAGERIAL $\left._{\mathrm{t} *} \mathrm{E}_{\mathrm{t}}\right)+\varepsilon_{\mathrm{t}}$ 
Model pengujian hipotesis 3:
$\mathrm{E}_{\mathrm{t}+1}=\beta 0+\beta 1 \mathrm{E}_{\mathrm{t}}+\beta 2$ LPNBTD $_{\mathrm{t}}+\beta 3\left(\mathrm{E}_{\mathrm{t}}\right.$ * LPNBTD $\left._{\mathrm{t}}\right)+\beta 4$ MANAGERIAL $_{\mathrm{t}}+$ $\beta 5\left(\right.$ MANAGERIAL $\left._{\mathrm{t} *} \mathrm{E}_{\mathrm{t}}\right)+\varepsilon_{\mathrm{t}}$

Model pengujian hipotesis 4:

$$
\begin{aligned}
\mathrm{E}_{\mathrm{t}+1}= & \beta 0+\beta 1 \mathrm{E}_{\mathrm{t}}+\beta 2 \text { LNNBTD }_{\mathrm{t}}+\beta 3\left(\mathrm{E}_{\mathrm{t} *} \text { LNNBTD }_{\mathrm{t}}\right)+\beta 4 \text { MANAGERIAL }_{\mathrm{t}}+ \\
& \beta 5\left(\text { MANAGERIAL }_{\mathrm{t} *} \mathrm{E}_{\mathrm{t}}\right)+\varepsilon_{\mathrm{t}}
\end{aligned}
$$

\begin{tabular}{cl}
\hline Variabel & \multicolumn{1}{c}{ Keterangan } \\
\hline $\mathrm{E}_{\mathrm{t}+1}$ & EPS pada tahun $t+1$ \\
$\mathrm{E}_{\mathrm{t}}$ & EPS pada tahun $t$ \\
LPNBTD $_{\mathrm{t}}$ & dummy variable, bernilai 1 untuk perusahaan dengan nilai \\
& NBTD positif berada pada kuartil tertinggi di setiap tahun, dan \\
& bernilai 0 untuk kondisi sebaliknya. \\
LNNBTD $_{\mathrm{t}}$ & dummy variable, bernilai 1 untuk perusahaan dengan nilai \\
& NBTD negatif berada pada kuartil terendah di setiap tahun, \\
& dan bernilai 0 untuk kondisi sebaliknya. \\
LPABTD $_{\mathrm{t}}$ & dummy variable, bernilai 1 untuk perusahaan dengan nilai \\
& ABTD positif berada pada kuartil tertinggi di setiap tahun, dan \\
& bernilai 0 untuk kondisi sebaliknya. \\
LNABTD $_{\mathrm{t}}$ & dummy variable, bernilai 1 untuk perusahaan dengan nilai \\
& ABTD negatif berada pada kuartil terendah di setiap tahun, dan \\
& bernilai 0 untuk kondisi sebaliknya. \\
MANAGERIAL & dummy variable, bernilai 1 untuk perusahaan mempunyai \\
& kepemilikan manajerial, dan bernilai 0 untuk kondisi \\
& sebaliknya.
\end{tabular}

\section{Keterangan tambahan:}

$B_{0}=$ konstanta

$B_{1}, B_{2}, B_{3}, B_{4}, B_{5} \quad=$ koefisien persamaan regresi

$\varepsilon \mathrm{t}=$ error

Sumber: Tang dan Firth (2012)

\section{HASIL DAN PEMBAHASAN}

\section{Seleksi Sampel}

Dalam penelitian ini, populasi meliputi seluruh perusahaan manufaktur yang terdaftar di Bursa Efek Indonesia pada tahun 2011 sampai tahun 2014. Total perusahaan sampel yang berhasil diperoleh melalui metode purposive sampling adalah 50 perusahaan selama setahun. Penelitian ini menggunakan fokus pengamatan 2 tahun sehingga fokus sampel penelitian adalah sebanyak 100 perusahaan. Variabel dalam model penelitian memerlukan data periode $\mathrm{t}-1$ maupun t+1 sehingga periode pengamatan menjadi 4 tahun dengan jumlah sampel keseluruhan adalah 200 perusahaan. Proses pemilihan sampel bisa dilihat pada tabel 3

\begin{tabular}{ll}
\hline Kelompok Sampel & Total \\
\hline Perusahaan manufaktur yang sudah terdaftar di BEI tahun & 127 \\
2011 dan masih terdaftar pada tahun 2014 & \\
Perusahaan yang mengalami kerugian komersial dan fiskal & $(57)$ \\
Laporan Keuangan tidak disajikan dalam rupiah & $(15)$ \\
Data tidak lengkap & $(5)$ \\
Total perusahaan sampel yang akan diuji & 50 \\
Total sampel dalam fokus penelitian (Tahun 2012 s.d 2013) & 100 \\
Total sampel dalam periode pengamatan (Tahun 2012 s.d 2014) & 200 \\
\hline
\end{tabular}

Tabel 2

Keterangan Variabel Model Persistensi Laba

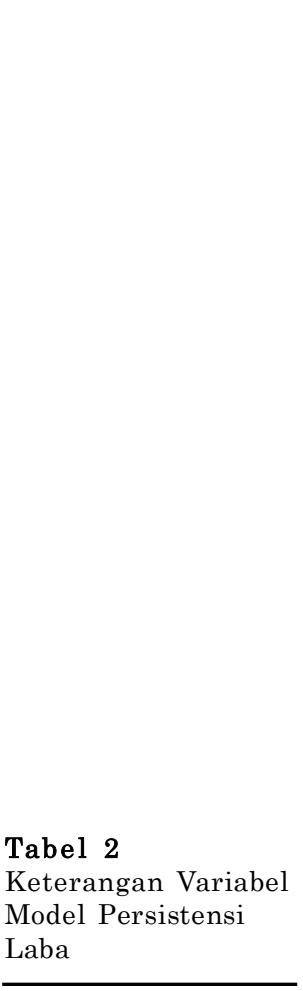




\section{Pengaruh Book Tax \\ Differences...}

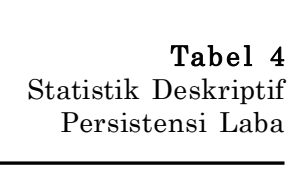

Tabel 5

Persentase Total Variabel Dummy

Tabel 6 Hasil Uji t

\section{Statistik Deskriptif Model Persistensi Laba}

Pengukuran persistensi laba pada model penelitian ini menggunakan nilai laba bersih per lembar saham pada tahun $t$ dan $t+1$. Nilai minimum persistensi laba pada tahun $t$ sebesar 1,03 sedangkan nilai minimum pada tahun $t+1$ sebesar 0,19 . Nilai minimum tersebut adalah nilai laba per lembar saham PT Charoen Pokphand Indonesia Tbk pada tahun 2012 dan 2013. perusahaan yang mengalami kerugian tidak digunakan sebagai sampel penelitian sehingga tidak ada Et dan Et+1 yang bernilai negatif. Nilai rata-rata laba bersih per lembar saham pada $t+1$ lebih besar daripada nilai rata-rata pada t, hal tersebut menunjukkan bahwa ratarata perusahaan manufaktur mengalami kenaikan laba dari tahun 2012 ke tahun 2013.

Penelitian ini menggunakan lima variabel dummy. Variabel tersebut adalah variabel LPABTD, LNABTD, LPNBTD, LNNBTD, dan MANAGERIAL. Persentase total variabel dummy bisa dilihat pada tabel 5 .

\begin{tabular}{lrrrrr}
\hline & N & Minimum & Maximum & Mean & $\begin{array}{c}\text { Std. } \\
\text { Deviation }\end{array}$ \\
\hline Et_1 & 100 &, 19 & 17621,00 & 1152,7923 & 3343,18019 \\
Et & 100 & 1,03 & 16515,00 & 1097,3695 & 2958,00637 \\
Valid N (listwise) & 100 & & & & \\
\hline
\end{tabular}

Sumber: data telah diolah kembali

\begin{tabular}{ccc}
\hline Variabel Dummy & Dummy=1 & Dummy=0 \\
\hline LPABTD & $18 \%$ & $82 \%$ \\
LNABTD & $8 \%$ & $92 \%$ \\
LPNBTD & $7 \%$ & $93 \%$ \\
LNNBTD & $19 \%$ & $81 \%$ \\
MANAGERIAL & $53 \%$ & $47 \%$ \\
\hline
\end{tabular}

Sumber: data telah diolah kembali

\section{Hasil Regresi Model Persistensi Laba}

Dari hasil analisis regresi menunjukkan bahwa variabel book tax differences (BTD) berpengaruh terhadap persistensi laba dengan nilai signifikansi sebesar 0,989 dan variabel struktur kepemilikan saham manajerial berpengaruh terhadap persistensi laba dengan signifikansi sebesar 0,096.

\begin{tabular}{lrl}
\hline \multicolumn{1}{c}{ Model } & $\mathrm{t}$ & Sig. \\
\hline & &, 000 \\
BTDt &, 014 &, 989 \\
MANAGERIAL & $-1,680$ &, 096 \\
\hline
\end{tabular}

\section{Model 1 (persistensi laba dengan komponen LPABTD)}

Model persistensi laba yang pertama meregresikan komponen LPABTD untuk membuktikan bahwa perusahaan yang memiliki komponen selisih laba akuntansi dan laba pajak dari sumber abnormal yang positif dan besar memiliki persistensi laba lebih rendah daripada perusahaan lainnya yang tidak memiliki komponen LPABTD tersebut. Variabel Et secara individu mempengaruhi variabel Et+1 secara searah atau positif dengan sig. 0,000. Variabel Et menunjukkan persistensi laba pada perusahaan lain yang tidak memiliki komponen LPABTD. Sedangkan perusahaan yang memiliki komponen LPABTD ditentukan dengan menambah koefisien variabel Et dengan koefisien interaksi yaitu berupa variabel Et*LPABTD. 
Hasil regresi menunjukkan bahwa persistensi laba pada perusahaan yang tidak memiliki komponen LPABTD adalah 1,107 sedangkan persistensi laba pada perusahaan yang memiliki komponen LPABTD sebesar 1,21. Hasil ini menunjukkan bahwa persistensi laba pada perusahaan yang memiliki komponen LPABTD lebih besar daripada perusahaan lain yang tidak memiliki komponen LPABTD. Hasil tersebut tidak sesuai dengan hipotesis yang dibuat sebelumnya, namun konsisten dengan penelitian (Wardana dan Martani, 2014). Perusahaaan yang memiliki komponen LPABTD memberikan informasi bahwa perusahaan melakukan perencanaan pajak. Perusahaan yang melakukan perencanaan pajak maka akan memiliki persistensi laba yang lebih baik karena dianggap sebagai aktivitas yang meningkatkan nilai perusahaan. Aktivitas ini didorong oleh teori signaling, yaitu memberikan sinyal kemakmuran terhadap stakeholders. Perencanaan pajak merupakan salah satu cara dalam penghematan pajak yang harus dibayar perusahaan melalui cara yang legal. Penghematan pajak tersebut bisa digunakan untuk kegiatan investasi perusahaan.

$$
\begin{aligned}
\mathbf{E}_{\mathrm{t}+1}= & -33,172+1,107 \mathrm{E}_{\mathrm{t}}-207,026 \operatorname{LPABTD}_{\mathrm{t}}+0,103\left(\mathrm{E}_{\mathrm{t}} * \text { LPABTD }_{\mathrm{t}}\right)+ \\
& 16,311 \text { MANAGERIAL }_{\mathrm{t}}-0,082\left(\text { MANAGERIAL }_{\mathrm{t}} * \mathrm{E}_{\mathrm{t}}\right)+\varepsilon_{\mathrm{t}}
\end{aligned}
$$

\begin{tabular}{lr}
\hline \multicolumn{1}{c}{ Variabel } & Koefisien \\
\hline Et & 1,107 \\
LPABTD & $-207,026$ \\
EtLPABTD & 0,103 \\
MANAGERIAL & 16,311 \\
EtMANAGERIAL & $-0,082$ \\
\hline
\end{tabular}

Sumber: data telah diolah kembali

\section{Model 2 (persistensi laba dengan komponen LNABTD)}

Model persistensi laba yang kedua meregresikan komponen LNABTD untuk membuktikan bahwa perusahaan yang memiliki komponen selisih laba akuntansi dan laba pajak dari sumber abnormal yang negatif dan besar memiliki persistensi laba lebih besar daripada perusahaan lainnya yang tidak memiliki komponen LNABTD tersebut. Persistensi laba perusahaan tanpa komponen LNABTD adalah 1,126 sedangkan persistensi laba perusahaan yang memiliki komponen LNABTD adalah sebesar 1,129 . Nilai persistensi laba perusahaan yang yang memiliki komponen LNABTD didapatkan dari penjumlahan koefisien variabel Et sebesar 1,126 dengan koefisien interaksi E*LNABTD sebesar 0,003.

Hasil pengujian hipotesis kedua pada tabel 8 menunjukkan bahwa perusahaan yang memiliki komponen LNABTD memiliki persistensi laba yang lebih tinggi daripada perusahaan lain yang tidak memiliki komponen LNABTD. Hasil ini berbeda dengan hipotesis yang dibuat sebelumnya tetapi konsisten dengan hasil penelitian (Wardana dan Martani, 2014). Sama halnya dengan perusahaan yang memiliki komponen LPABTD, perusahaan yang memiliki komponen LNABTD memiliki persistensi laba yang lebih tinggi daripada perusahaan lain tanpa komponen tersebut karena adanya indikasi bahwa perusahaan melakukan perencanaan pajak.

\begin{tabular}{|c|c|}
\hline Variabel & Koefisien \\
\hline $\mathrm{Et}$ & 1,126 \\
\hline LNABTD & 28,277 \\
\hline EtLNABTD & 0,003 \\
\hline MANAGERIAL & 13,312 \\
\hline EtMANAGERIAL & $-0,088$ \\
\hline
\end{tabular}

$$
\begin{aligned}
\mathbf{E}_{\mathrm{t}+1}= & -62,434+1,126 \mathrm{E}_{\mathrm{t}}+28,277 \text { LNABTD }_{\mathrm{t}}+0,003\left(\mathrm{E}_{\mathrm{t}} \text { LNABTD }_{\mathrm{t}}\right)+13,312 \\
& \text { MANAGERIAL }_{\mathrm{t}}-0,088\left(\text { MANAGERIAL }_{\mathrm{t}} * \mathrm{E}_{\mathrm{t}}\right)+\boldsymbol{\varepsilon}_{\mathrm{t}}
\end{aligned}
$$

Sumber: data telah diolah kembali
Tabel 7

Hasil Koefisien Model 1

Tabel 8

Hasil Regresi

Model 2 


\section{Pengaruh \\ Book Tax \\ Differences...}

680

Tabel 9

Hasil Regresi

Model 3

\section{Model 3 (persistensi laba dengan komponen LPNBTD)}

Model persistensi laba dengan komponen LPNBTD digunakan untuk menguji tingkat persistensi laba pada perusahaan yang memiliki komponen NBTD bernilai positif dan besar dengan perusahaan tanpa komponen LPNBTD. Nilai koefisien Et pada hasil regresi model persistensi laba adalah nilai persistensi laba untuk perusahaan yang tidak memiliki komponen LPNBTD. Sedangkan nilai persistensi laba pada perusahaan yang memiliki komponen LPNBTD diperoleh dari penjumlahan koefisien variabel Et dengan koefisien interaksi yaitu Et*LPNBTD.

Berdasarkan output hasil regresi pada SPSS, koefisien Et sebesar 1,126 sedangkan dari hasil penjumlahan koefisien Et dan koefisisien Et*LPNBTD adalah 1,135. Dapat disimpulkan bahwa perusahaan yang memiliki komponen LPNBTD memiliki persistensi laba yang lebih tinggi daripada perusahaan lain yang tidak memiliki komponen LPNBTD. Dapat disimpulkan bahwa bahwa perusahaan yang memiliki komponen LPNBTD memiliki persistensi laba yang lebih tinggi daripada perusahaan lain yang tidak memiliki komponen LPNBTD. Jadi laba semakin persisten jika laba tersebut dihasilkan oleh perusahaan yang memiliki BTD yang positif dan besar serta bersumber dari karakteristik normal.

Hasil regresi ini konsisten dengan hipotesis awal yang dibuat peneliti. Selain itu hasil ini juga sesuai dengan penelitian (Sismi dan Martani, 2014). Hal ini dikarenakan LPNBTD terjadi karena selisih laba akuntansi dan laba pajak akibat perbedaan peraturan akuntansi dan perpajakan serta sesuai dengan karakteristik perusahaan.

$$
\begin{aligned}
\mathrm{E}_{\mathrm{t}+1}= & -59,177+1,126 \mathrm{E}_{\mathrm{t}}+13,471 \operatorname{LPNBTD}_{\mathrm{t}}+0,009\left(\mathrm{E}_{\mathrm{t}} * \operatorname{LPNBTD}_{\mathrm{t}}\right)+9,056 \\
& \text { MANAGERIAL }_{\mathrm{t}}-0,087\left(\text { MANAGERIAL }_{\mathrm{t}} * \mathrm{E}_{\mathrm{t}}\right)+\varepsilon_{\mathrm{t}}
\end{aligned}
$$

\begin{tabular}{lc}
\hline \multicolumn{1}{c}{ Variabel } & Koefisien \\
\hline Et & 1,126 \\
LPNBTD & 13,471 \\
EtLPNBTD & 0,009 \\
MANAGERIAL & 9,056 \\
EtMANAGERIAL & $-0,087$ \\
\hline
\end{tabular}

Sumber: data telah diolah kembali

\section{Model 4 (persistensi laba dengan komponen LNNBTD)}

Model persistensi laba yang keempat meregresikan komponen LNNBTD untuk membuktikan bahwa perusahaan yang memiliki komponen selisih laba akuntansi dan laba pajak dari sumber normal yang negatif dan besar memiliki persistensi laba lebih rendah daripada perusahaan lainnya yang tidak memiliki komponen LNNBTD tersebut. Nilai persistensi laba pada perusahaan yang memiliki komponen LNNBTD terbukti lebih rendah daripada perusahaan lain yang tidak memiliki komponen LNNBTD. Hasil penelitian menunjukkan bahwa persistensi laba perusahaan tanpa LNNBTD adalah 1,129 sedangkan perusahaan yang memiliki komponen LNNBTD adalah sebesar 0,485. Jadi, komponen LNNBTD mengurangi persistensi laba perusahaan.

Penelitian ini konsisten dengan hipotesis yang dibuat sebelumnya. Hasil regresi sesuai dengan hasil penelitian Tang dan Firth (2012), Sismi dan Martani (2014), serta Wardana dan Martani (2014). Hal ini dikarenakan perusahaan dengan komponen LNNBTD tidak melakukan perencanaan pajak yang efektif. LNNBTD ini menjadikan timbulnya aset pajak tangguhan pada perusahaan akibat laba fiskal yang lebih besar dibandingkan dengan laba komersial. Pengakuan aset pajak tangguhan ini mengakibatkan persistensi laba perusahaan menjadi semakin rendah karena aset pajak tangguhan belum tentu dapat direalisasikan dimasa yang akan datang. 


$$
\begin{aligned}
\mathrm{E}_{\mathrm{t}+1}= & -39,147+1,129 \mathrm{E}_{\mathrm{t}}+190,231 \text { LNNBTD }_{\mathrm{t}}-0,644\left(\mathrm{E}_{\mathrm{t}} \text { LNNBTD }_{\mathrm{t}}\right)-27,268 \\
& \text { MANAGERIAL }_{\mathrm{t}}+0,009\left(\text { MANAGERIAL }_{\mathrm{t}} * \mathrm{E}_{\mathrm{t}}\right)+\stackrel{\mathrm{a}}{\mathrm{t}}^{\mathrm{m}}
\end{aligned}
$$

\begin{tabular}{lc}
\hline \multicolumn{1}{c}{ Variabel } & Koefisien \\
\hline Et & 1,129 \\
LNNBTD & 190,231 \\
EtLNNBTD & $-0,644$ \\
MANAGERIAL & $-27,268$ \\
EtMANAGERIAL & 0,009 \\
\hline
\end{tabular}

Sumber: data telah diolah kembali

\section{Model Persistensi Laba dengan Struktur Kepemilikan Saham}

Nilai persistensi laba untuk perusahaan dengan kepemilikan saham manajerial ditunjukkan dengan penjumlahan nilai koefisien variabel Et dengan variabel interaksi Et*MANAGERIAL. Sedangkan perusahaan lain tanpa struktur kepemilikan manajerial ditunjukkan dengan koefisien variabel Et. Saat dilakukan regresi model persistensi laba pertama (dengan komponen LPABTD), model persistensi laba kedua (dengan komponen LNABTD), dan model persistensi laba ketiga (dengan komponen LPNBTD) menunjukkan persistensi laba semakin rendah apabila perusahaan memiliki kepemilikan manajerial. Namun, hasil ini berbeda saat diregresikan dengan model persistensi laba yang keempat (dengan komponen LNNBTD). Perusahaan yang memiliki struktur kepemilikan saham manajerial memiliki persistensi laba lebih tinggi dibandingkan perusahaan lain yang tidak memiliki struktur kepemilikan saham manajerial. Karena menghasilkan dua kemungkinan, informasi struktur kepemilikan saham menjadi tidak informatif untuk menentukan tingkat persistensi laba pada perusahaan. Hal ini dikarenakan proporsi struktur kepemilikan saham manajerial yang dimiliki pihak manajemen relatif kecil.

\section{SIMPULAN}

Perusahaan yang memiliki selisih laba akuntansi dan laba pajak dari sumber abnormal yang besar baik positif maupun negatif (LPABTD dan LNABTD) serta LPNBTD memiliki persistensi laba yang lebih tinggi daripada perusahaan lain tanpa komponen tersebut. Hal tersebut mengindikasikan bahwa perusahaan dengan komponen LPABTD dan LNABTD melakukan perencanaan pajak. Perusahaan yang melakukan perencanaan pajak memiliki persistensi laba yang lebih tinggi. sedangkan LPNBTD terjadi karena selisih laba akuntansi dan laba pajak akibat perbedaan peraturan akuntansi dan perpajakan serta sesuai dengan karakteristik perusahaan.

Berbeda dengan perusahaan dengan book tax differences negatif yang besar dari sumber normal (LNNBTD) memiliki persistensi laba yang lebih rendah dibandingkan perusahaan lain tanpa komponen LNNBTD. Hal ini disebabkan aset pajak tangguhan yang terbentuk akibat LNNBTD belum tentu bisa direalisasikan di tahun depan. Hasil analisis struktur kepemilikan saham manajerial menunjukkan dua hasil kemungkinan. Jadi, informasi mengenai struktur kepemilikan saham manajerial menjadi kurang informatif untuk menentukan tingkat persistensi laba perusahaan.

Keterbatasan dalam penelitian ini adalah variabel yang digunakan dalam persamaan persistensi laba hanya menggunakan komponen large BTD saja dan software statistik yang digunakan (SPSS) tidak mampu membedakan tipe data yang disusun berdasarkan runtun waktu (time-series) atau disusun berdasarkan subjek penelitian (cross section). Sehingga kurang cocok jika dihadapkan dalam penelitian ini dengan data yang berupa data panel.
Tabel 10

Hasil Regresi

Model 4 


\section{Pengaruh \\ Book Tax \\ Differences...}

682

Peneliti selanjutnya diharapkan menambah dan menjelaskan lebih lengkap mengenai komponen book tax differences lainnya. Dengan cara menambahkan komponen small BTD, yaitu meliputi small positive abnormal book tax differences (SPABTD), small negative abnormal book tax differences (SNABTD), small positive normal book tax differences (SPNBTD) dan small negative normal book tax differences (SNNBTD). Selain itu untuk hasil yang lebih akurat sebaiknya peneliti selanjutnya menggunakan software Economic Views (Eviews) karena data yang digunakan adalah data runtun waktu silang.

Penelitian ini dapat digunakan investor sebagai alat penilaian kualitas laba pada perusahaan-perusahaan yang terdaftar di BEI berupa laba yang persisten, yang diperoleh dari informasi terkait perbedaan laba akuntansi dan laba fiskal. Sehingga investor bisa mengambil keputusan yang tepat dalam menentukan pilihan atas investasi. Selain itu penelitian ini juga dapat dijadikan dasar pertimbangan pihak manajemen perusahaan dalam melakukan transaksi-transaksi terkait aktivitas perusahaan. Karena akan ada dampak pajak yang melekat pada setiap aktivitas perusahaan yang menimbulkan perbedaan laba akuntansi dengan laba fiskal, sehingga memengaruhi persistensi laba perusahaan.

\section{DAFTAR PUSTAKA}

Beaver, W. H. 2002. "Perspectives on Recent Capital Market Research". The Accounting Review, Vol. 77, No. 2, hlm: 453-474.

Boediono, G. S. 2005. "Kualitas Laba: Studi Pengaruh Mekanisme Corporate Governance dan Dampak Manajemen Laba Dengan Menggunakan Analisis Jalur". Artikel dipresentasikan pada Simosium Nasional Akuntansi VIII, di Solo.

Boulton, T. J., S. B. Smart, dan C. J. Zutter. 2011. "Earnings Quality and International IPO Underpricing". The Accounting Review, Vol. 86, No. 2, hlm: 483505.

Harahap, S. S. 2011. Analisis Kritis Atas Laporan Keuangan. Jakarta: Raja Grafindo Persada.

Khafid, M. 2012. "Pengaruh tata kelola perusahaan (corporate governance) dan struktur kepemilikan terhadap persistensi laba". Jurnal Dinamika Akuntansi, Vol. 4, No. 2, hlm: 139-148.

Siallagan, H., dan M. u. Machfoedz. 2006. "Mekanisme Corporate Governance, Kualitas Laba dan Nilai Perusahaan". Artikel dipresentasikan pada Simposium Nasional Akuntansi IX, di Padang.

Sismi, A. L., dan D. Martani. 2014. "Pengaruh Perbedaan Laba Akuntansi dengan Laba Pajak dan Kepemilikan Keluarga terhadap Persistensi Laba". Artikel dipresentasikan pada Simposium Nasional Akuntansi XVII, di Mataram.

Tang, T. Y. H., dan M. Firth. 2012. "Earnings Persistence and Stock Market Reactions to the Different Information in Book-Tax Differences: Evidence from China". The International Journal of Accounting, Vol. 47, No., hlm: 369-397.

Tucker, J. W., dan P. A. Zarowin. 2006. "Does Income Smoothing Improve Earnings Informativeness?". The Accounting Review, Vol. 81, No. 1, hlm: 251-270.

Wardana, D. P., dan D. Martani. 2014. "Pengaruh Book-tax Differences dan Struktur Kepemilikan terhadap Relevansi Laba". Artikel dipresentasikan pada Simposium Nasional Akuntansi XVII, di Mataram. 